Narrative Works

Issues, Investigations, \& Interventions

\title{
The Enacted Narrative: A Group-Based Trauma Repair Approach for Veterans Who Have a Post-Traumatic Stress Injury
}

\section{Marvin Westwood}

Volume 8, Number 1-2, 2018

URI: https://id.erudit.org/iderudit/1059851ar

DOI: https://doi.org/10.7202/1059851ar

See table of contents

Publisher(s)

Centre for Interdisciplinary Research on Narrative, St. Thomas University

ISSN

1925-0622 (digital)

Explore this journal

Cite this document

Westwood, M. (2018). The Enacted Narrative: A Group-Based Trauma Repair Approach for Veterans Who Have a Post-Traumatic Stress Injury. Narrative Works, 8(1-2). https://doi.org/10.7202/1059851ar

\section{Article abstract}

In this 2017 John McKendy Memorial Lecture, Dr. Marvin Westwood discussed two group-based interventions for veterans who have a post-traumatic stress-injury—guided autobiography and therapeutic enactment—as a trans-theoretical model for change. Narrative-based therapeutic enactment has been highly effective for traumatized individuals-both military and civilian. The presentation included video clips illustrating how the approach is applied in work with Canadian veterans who have operational stress injuries.
This document is protected by copyright law. Use of the services of Érudit (including reproduction) is subject to its terms and conditions, which can be viewed online.

https://apropos.erudit.org/en/users/policy-on-use/ 


\title{
NARRATIVE WORKS \\ Issues, Investigations, \& Interventions
}

\section{OUTSIDE THE BOX}

\section{The Enacted Narrative: A Group-Based Trauma Repair Approach for Veterans Who Have a Post- Traumatic Stress Injury ${ }^{1}$}

\author{
Marvin Westwood \\ University of British Columbia
}

\begin{abstract}
In this 2017 John McKendy Memorial Lecture, Dr. Marvin Westwood discussed two group-based interventions for veterans who have a post-traumatic stress-injury-guided autobiography and therapeutic enactment-as a transtheoretical model for change. Narrative-based therapeutic enactment has been highly effective for traumatized individuals - both military and civilian. The presentation included video clips illustrating how the approach is applied in work with Canadian veterans who have operational stress injuries. [Video Link]
\end{abstract}

Marvin "Marv" Westwood, $\mathrm{PhD}$, is Professor Emeritus of Counselling Psychology in the Faculty of Educational and Counselling Psychology, and Special Education at the University of British Columbia. He currently has a post-retirement appointment to the Faculty of Education at UBC. His major areas of teaching and research focused on development, teaching, and delivery of group-based approaches for counselling clients; and men's psychological health. He developed the UBC Veterans Transition Program to help promote recovery from war-related stress injuries, for which he received both the Queen's Golden and Diamond Jubilee Medals in 2005 and 2013. In 2012, he established the Centre for Group Counselling and Trauma (currently he is Senior Consultant to the Centre).

1 On October 25, 2018, Dr. Marvin Westwood presented the 11th annual John McKendy Memorial Lecture on Narrative at St. Thomas University. The annual lecture, sponsored by the Centre for Interdisciplinary Research on Narrative (CIRN), is named for John McKendy, $\mathrm{PhD}$, who died tragically in 2008. He was a member of the Sociology Department at St. Thomas University and one of the founding members of CIRN. Dr. Westwood has graciously permitted Narrative Works to publish the video of his lecture.

NARRATIVE WORKS: ISSUES, INVESTIGATIONS, \& INTERVENTIONS 8(1/2), 99

CMarvin Westwood, 2018 